\title{
Demography and population dynamics in the elephants Loxodonta africana of Addo Elephant National Park, South Africa: is there evidence of density dependent regulation?
}

\author{
Katie F. Gough and Graham I. H. Kerley
}

\begin{abstract}
Density dependence of the Addo Elephant National Park (South Africa) elephants Loxodonta africana was assessed using a long-term data set. Estimated carrying capacity is $0.1-0.5$ elephants $\mathrm{km}^{-2}$ but stocking rates have been up to 4 elephants $\mathrm{km}^{-2}$. Population growth rate was found to be positively correlated with increasing density. There was no relationship between birth rate, the age of first calving or calf sex ratio and elephant density but there was a positive relationship between birth rate and rainfall during conception year. Mortality rates, particularly for juveniles, were low, and mean inter-calf interval was 3.3 years. There is no evidence of density dependent regulation in this population,
\end{abstract}

despite the population being consistently above the estimated sustainable carrying capacity and a loss of phytomass and biodiversity. This is interpreted in light of the characteristics of the aseasonal habitat, succulent thicket vegetation and the ability of elephants to utilize accumulated vegetation biomass. These findings indicate that density dependence should not be considered as an option in the control of elephant numbers in this Park, or where elephant resources are not seasonally limited.

Keywords Addo Elephant National Park, density dependence, elephant, Loxodonta africana, population regulation, South Africa.

\section{Introduction}

Elephant Loxodonta africana population regulation is increasingly becoming an issue in many conservation areas throughout Africa. Given their large body size elephants have the ability to transform habitats, particularly when at high densities. Successful management leads to large elephant populations within confined areas, which may lead to a loss of biodiversity (Van Wyk \& Fairall, 1969; Laws, 1970; Barnes, 1983; Western \& Gichohi, 1989; Lewis, 1991; Ben-Shahar, 1993; Moolman \& Cowling, 1994; Cumming et al., 1997). The challenge to conservation managers is to limit elephant population size without resorting to culling. One management approach may be to rely on the regulation of population size through density dependent effects (Laws, 1970; Hanks \& McIntosh, 1973; van Aarde et al., 1999). Consequently, understanding how density dependence influences elephant population dynamics is critical to the future management of elephants. Here we assess the evidence for density dependent effects in a small, closed population of elephants in South Africa.

Katie F. Gough (Corresponding author) and Graham I. H. Kerley Centre for African Conservation Ecology, Department of Zoology, PO Box 77000, Nelson Mandela Metropolitan University, 6031, South Africa.

E-mail katie.gough2@nmmu.ac.za

Received 17 May 2005. Revision requested 12 October 2005 Accepted 30 March 2006
Fowler (1987) reviewed the evidence for density dependence in large mammals and concluded that the vital rates (fecundity and mortality) may change as a result of changes in food resources. Gaillard et al. (1998, 2000) determined that, although adult survival rate has a greater effect on population growth rate than juvenile survival rate, it had higher elasticity and appeared to be buffered against temporal variation. They concluded that juvenile survival was more sensitive to density dependence. There is a sequence of changes in vital rates as population density increases towards maximal levels: increase in juvenile mortality rate, increase in age of first reproduction, decrease in adult female reproductive rate, and increase in adult mortality rate (Gaillard et al., 2000; Eberhardt, 2002). These changes have been reported in a number of species (e.g. red deer Cervus elephus, Clutton-Brock et al., 1987; Soay sheep Ovis aries, Clutton-Brock et al., 1996).

The nutritional status of females may influence the sex of offspring (Trivers \& Willard, 1973); hence, populations operating under density limited resource availability may show skewed sex ratios. Changes in the birth sex ratio have been attributed to density dependence (Kruuk et al., 1999; Mysterud et al., 2000). Males are more expensive than female offspring in terms of parental investment and future breeding opportunities for a number of species, including elephant (CluttonBrock et al., 1981; Lee \& Moss, 1986; Wolff, 1988; Clark et al., 1990). We therefore hypothesize that a population 
operating under density limited resource availability may show a higher proportion of females at birth.

Density induced population regulation has been noted in a number of elephant populations (Buss \& Savidge, 1966; Laws, 1969; Hanks \& McIntosh, 1973; Dunham, 1988; van Aarde et al., 1999). The density at which these effects operate varies with the population and habitat type. Van Jaarsfeld et al. (1999) found no evidence of density dependent effects in South African elephant populations with a mean density of 0.33 elephants $\mathrm{km}^{-2}$. However, van Aarde et al. (1999) found evidence to suggest density dependence at the subpopulation level in the Kruger National Park at a density of 0.37 elephants $\mathrm{km}^{-2}$. The elephants of Addo Elephant National Park, the population reported on here, have been stocked at much higher levels, up to 4.0 elephants $\mathrm{km}^{-2}$, during the Park's 73-year history.

The Park's elephant density has been consistently higher than any estimated carrying capacities (sensu Zacharias, 2004) recommended to maintain the vegetation (e.g. 0.4 elephants $\mathrm{km}^{-2}$, Penzhorn et al., 1974; 0.25-0.54 elephants $\mathrm{km}^{-2}$, Boshoff et al., 2002). Since 1976 the population has been the subject of a number of intensive demographic studies (Hall-Martin, 1980; Whitehouse, 2001; K.F. Gough, unpub. data). This well studied population, occurring at high densities and faced with declining resources (Penzhorn et al., 1974), presents an ideal opportunity to investigate density dependent influences. This paper presents the findings of such an analysis.

\section{Methods}

\section{Population history}

The Addo Elephant National Park is c. $60 \mathrm{~km}$ north of Port Elizabeth in the Eastern Cape Province, South Africa. The Park was proclaimed in 1931 to protect the remaining 11 elephants in the region (Hoffman, 1993). It was fenced in 1954, restricting the then population of 22 elephants to $22.7 \mathrm{~km}^{2}$ (Hall-Martin, 1980) and preventing any natural emigration or immigration. The elephants of the Park were intensively studied from 1976 to 1979 (Hall-Martin, 1980) and from 1996 to the present (Whitehouse, 2001). The history of the population was reconstructed (Whitehouse, 2001), allowing detailed examination of long-term demography. Since the Park was fenced it has undergone five expansions, starting in 1977 (Lombard et al., 2001). The elephant population numbered 381 in December 2002, confined to a fenced area of $103 \mathrm{~km}^{2}$.

\section{Analysis}

Demographic analysis for the period 1976-2002 is presented here. Although the history of the population has been reconstructed, data prior to 1976 is not used as it is less reliable (Whitehouse \& Hall-Martin, 2000). The observed annual exponential rate of increase $(r)$ and the percentage population growth were calculated (Caughley \& Sinclair, 1994) as $r=\log _{\mathrm{e}}\left(N_{t+1} / N_{t}\right)$, where $N=$ population size and $t=$ time, and \% population growth $=\left(\mathrm{e}^{r}-1\right) 100$, respectively. The relationship between annual percentage population growth and density was investigated using linear regression. The influence of a delay in density dependent regulatory effects on population growth was assessed by lagging density data during calculations by 1, 2 and 3 years.

Female fecundity, as age of first calving, inter-calf interval, and birth rate were examined. The age of first calving and the inter-calf interval are maximum estimates as cows may have given birth to additional calves between recorded offspring or prior to their first recorded offspring (Whitehouse \& Hall-Martin, 2000). The calf sex ratio was expressed as a proportion (males/ (males + females)) where 0.5 reflects an equal sex ratio, higher values are male biased, and lower values are female biased (Wilson \& Hardy, 2002). The birth rate was derived following Moss (2001), adjusted to remove females unavailable for conception due to pregnancy. Thus, birth rate was calculated as (cows that gave birth in year $x$ )/(cows available to give birth in year $x$ ), where available is defined as all cows of breeding age minus cows that had given birth in the previous 22 months (gestation length). Breeding age was 9-55 years, the youngest and oldest ages of calving, respectively, recorded in the Park (1976-2003). Multiple linear regressions were used to compare the birth rate with density (elephants $\mathrm{km}^{-2}$ ) and rainfall (data from South African Weather Service) in the conception year as elephant conception rate can be influenced by rainfall (Moss, 2001). Rain occurs throughout the year in the Park with an annual mean of $392 \pm$ SD $111 \mathrm{~mm}$ (calculated for 1959-2003). There is no permanent natural surface water and water is provided by boreholes that feed 11 artificial water points.

The total number of elephants entering each of 17 age classes (year 0, 1, 2, 3, 4 and thereafter in 5 year categories, 5-9, 10-14,...,60-64) between 1976 and 2002 was summed and the total number of deaths in each age class used to calculate age-specific and sex-specific mortality.

\section{Results}

Elephant density fluctuated widely between 1976 and 2002 (Fig. 1) as the population grew and the area available increased through Park expansions. Mean density for the period 1976-2002 was $2.4 \pm$ SD 0.48 elephants $\mathrm{km}^{-2}$ (range 1.8-4). Annual population 


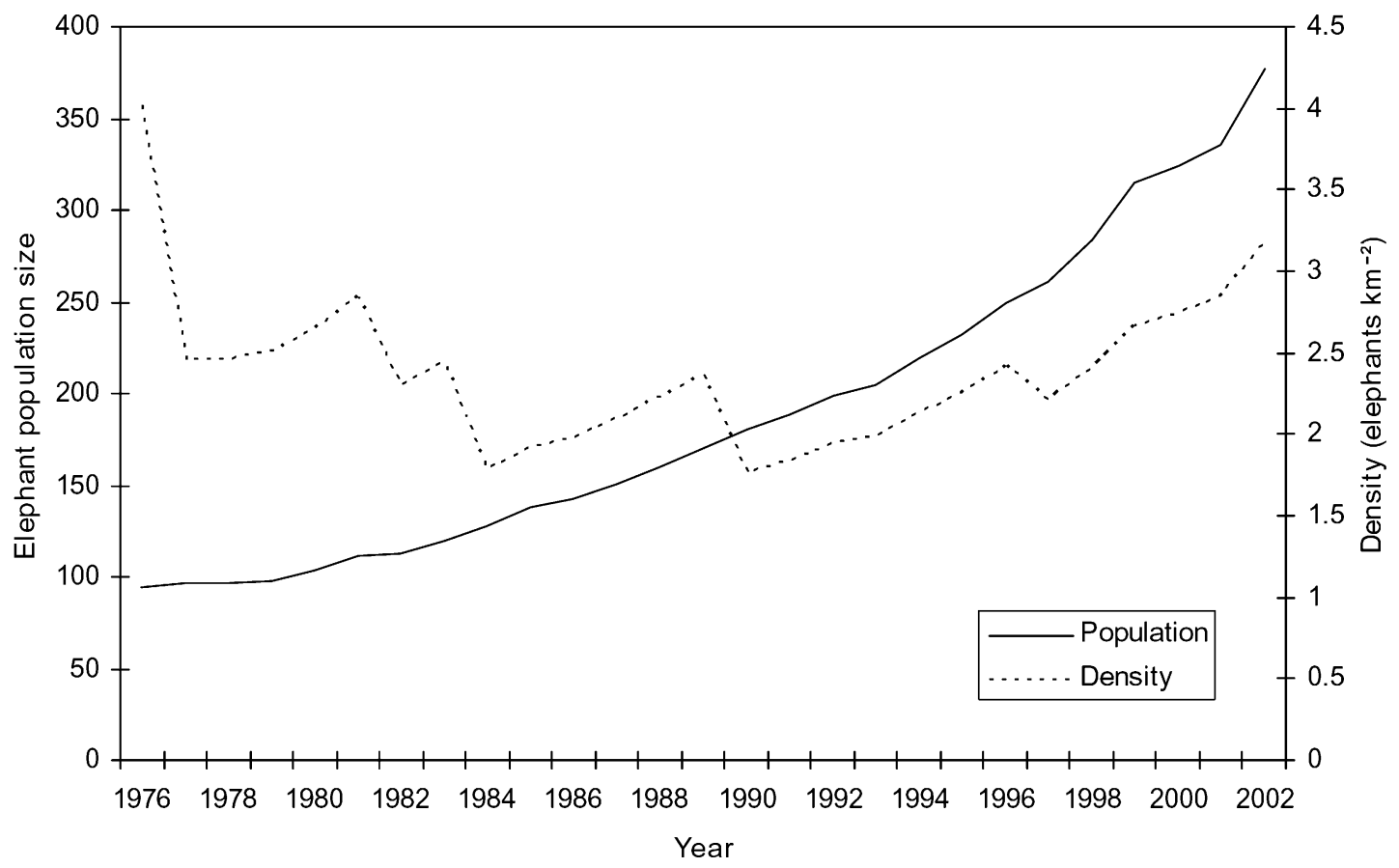

Fig. 1 Addo Elephant National Park elephant population size and density during 1976-2002. The park was enlarged in 1977, 1982, 1984, 1990 and 1997 (Lombard et al., 2001).

growth rate for the same period was $5.8 \pm$ SD $3.14 \%$ (range 0-13.3; Table 1). The population grew exponentially (exponential $R^{2}=0.99$, Fig. 2) and $r$ ranged from 0.0 to 0.12 (Table 1). A 3-year running mean produced a range of $r$ of 0.01-0.08 (Fig. 3).

Density and annual percentage population growth had a positive relationship $\left(R^{2}=0.17 ; \mathrm{df}=27 ; \mathrm{P}=0.03\right)$. There was no significant relationship between population growth rate and density when this was lagged by 1 $\left(R^{2}=0.01 ; \mathrm{P}=0.93\right), 2\left(R^{2}=0.02 ; \mathrm{P}=0.5\right)$ or 3 years $\left(R^{2}\right.$ $=0.04 ; \mathrm{P}=0.3)$. The number of years since each expansion was not a significant predictor of percentage population growth (Pearson product-moment correlation $=-0.32 ; \mathrm{n}=23 ; \mathrm{P}=0.13$ ).

Population density and $r$ had a positive relationship $\left(R^{2}=0.20 ; \mathrm{df}=27 ; \mathrm{P}=0.02\right)$, where the mean $r$ for the 1976-2002 period was $0.05 \pm$ SD 0.03 (range 0-0.12; Table 1). No significant relationships were found when the density data was adjusted for time lags of $1\left(R^{2}=\right.$ $0.01 ; \mathrm{P}=0.78), 2\left(R^{2}=0.02 ; \mathrm{P}=0.54\right)$ or 3 years $\left(R^{2}=\right.$ $0.05 ; \mathrm{P}=0.28)$.

The proportion of breeding females was calculated to determine if an increase in the proportion of breeding females over time could explain the significant relationship with population growth. The percentage of breeding females was $25.0-34.5 \%$ (mean $30.9 \%$ ) and there was no relationship with population growth rate (Spearman's rank correlation $=-0.074 ; \mathrm{P}=0.71 ; \mathrm{n}=$ 28).
Mean calf sex ratio for 1976-2003 was $0.54 \pm$ SD 0.188 (range $0.25-1.0 ; 200$ male calves; 176 female calves). The higher number of male calves born did not differ significantly from parity $\left(\chi^{2}=1.4 ; \mathrm{df}=1 ; \mathrm{P}>0.05\right)$. The sex ratio fluctuated annually (Table 1 ) but this was not related to density or rainfall. There was no relationship between the sex ratio of calves and density in conception year (Pearson product-moment correlation $=$ $0.021 ; \mathrm{P}=0.28$ ), density in birth year (Pearson productmoment correlation $=-0.088 ; \mathrm{P}=0.66$ ), rain in conception year (Pearson product-moment correlation $=$ -0.016 ; $\mathrm{P}=0.94$ ) or rain in the year prior to conception (Pearson product-moment correlation $=0.155 ; \mathrm{P}=0.56$ ).

Mean age of first calving was $12.3 \pm$ SD 1.73 years ( $\mathrm{n}$ $=62$ ). A birth rate for an age of first calving of 9 years was calculated but as only $0.89 \%$ of cows reproduced at this age birth rates for 10 and 11 years were also calculated $(23.21 \%$ of cows had had their first calf by 11 years, $50.89 \%$ by 12 years, and $91.07 \%$ by 15 years). The mean inter-calf interval for the period 1976-2003 was 3.3 \pm SD 0.77 years.

Elephants had a higher birth rate in wet years at all three ages of maturation (9 years $R^{2}=0.26, \beta=0.61, \mathrm{P}=$ $0.01 ; 10$ years $R^{2}=0.24, \beta=0.59, \mathrm{P}=0.01 ; 11$ years $R^{2}=$ $0.25, \beta=0.59, \mathrm{P}=0.01)$. However, the age of a cow at the birth of her first known calf was not correlated with rain in conception year (Spearman's rank correlation $=$ $-0.005 ; \mathrm{P}=0.97 ; \mathrm{n}=86 ; 1976-2003)$. There was no correlation between birth rate and population density in 
Table 1 End of year population sizes, annual births, deaths, calf sex ratio ( $>0.5$ male biased; $<0.5$ female biased), and growth and mortality rates for the Addo Elephant National Park elephant population, 1976-2003.

\begin{tabular}{|c|c|c|c|c|c|c|c|}
\hline Year & $\begin{array}{l}\text { Population size } \\
\text { at end of year }\end{array}$ & Births & Deaths & $\begin{array}{l}\text { Sex ratio } \\
(\mathrm{M} /(\mathrm{M}+\mathrm{F}))\end{array}$ & $\begin{array}{l}\text { Exponential rate } \\
\text { of increase }(r)\end{array}$ & $\begin{array}{l}\text { Population } \\
\text { growth (\%) }\end{array}$ & Mortality (\%) \\
\hline 1976 & 94 & 11 & 0 & 0.45 & 0.12 & 13.3 & 0.0 \\
\hline 1977 & 96 & 4 & 2 & 0.50 & 0.02 & 2.1 & 2.1 \\
\hline 1978 & 96 & 2 & 2 & 1.00 & 0.00 & 0.0 & 2.1 \\
\hline 1979 & 98 & 9 & 7 & 0.38 & 0.02 & 2.1 & 3.1 \\
\hline 1980 & 103 & 5 & 0 & 0.40 & 0.05 & 5.1 & 0.0 \\
\hline 1981 & 111 & 12 & 4 & 0.25 & 0.07 & 7.8 & 3.6 \\
\hline 1982 & 113 & 4 & 2 & 0.75 & 0.02 & 1.8 & 1.8 \\
\hline 1983 & 120 & 8 & 1 & 0.75 & 0.06 & 6.2 & 0.8 \\
\hline 1984 & 128 & 9 & 1 & 0.67 & 0.06 & 6.7 & 0.8 \\
\hline 1985 & 138 & 10 & 0 & 0.30 & 0.08 & 7.8 & 0.0 \\
\hline 1986 & 142 & 11 & 7 & 0.50 & 0.03 & 2.9 & 4.9 \\
\hline 1987 & 151 & 10 & 1 & 0.50 & 0.06 & 6.3 & 0.7 \\
\hline 1988 & 160 & 11 & 2 & 0.36 & 0.06 & 6.0 & 1.3 \\
\hline 1989 & 170 & 10 & 0 & 0.40 & 0.06 & 6.3 & 0.0 \\
\hline 1990 & 181 & 11 & 0 & 0.36 & 0.06 & 6.5 & 0.0 \\
\hline 1991 & 189 & 8 & 0 & 0.50 & 0.04 & 4.4 & 0.0 \\
\hline 1992 & 199 & 12 & 2 & 0.83 & 0.05 & 5.3 & 1.0 \\
\hline 1993 & 205 & 13 & 7 & 0.69 & 0.03 & 3.0 & 3.4 \\
\hline 1994 & 220 & 15 & 0 & 0.67 & 0.07 & 7.3 & 0.0 \\
\hline 1995 & 232 & 18 & 6 & 0.69 & 0.05 & 5.5 & 2.6 \\
\hline 1996 & 249 & 19 & 2 & 0.32 & 0.07 & 7.3 & 0.8 \\
\hline 1997 & 261 & 17 & 5 & 0.56 & 0.05 & 4.8 & 1.9 \\
\hline 1998 & 284 & 29 & 6 & 0.36 & 0.08 & 8.8 & 2.1 \\
\hline 1999 & 315 & 32 & 1 & 0.66 & 0.10 & 10.9 & 0.3 \\
\hline 2000 & 324 & 15 & 6 & 0.40 & 0.03 & 2.9 & 1.9 \\
\hline 2001 & 336 & 16 & 4 & 0.81 & 0.04 & 3.7 & 1.2 \\
\hline 2002 & 377 & 42 & 1 & 0.62 & 0.12 & 12.2 & 0.3 \\
\hline 2003 & 388 & 18 & 7 & 0.42 & 0.03 & 2.9 & 1.8 \\
\hline
\end{tabular}

conception year $\left(9\right.$ years $R^{2}=0.26, \beta=-0.31, \mathrm{P}=0.15$ 10 years $R^{2}=0.24, \beta=-0.24, \mathrm{P}=0.26 ; 11$ years $R^{2}=$ $0.25, \beta=-0.23, \mathrm{P}=0.29$ ). No significant relationship was found between the age of a cow at the birth of her first known calf and density in the year of conception (Spearman's rank correlation $=-0.136 ; \mathrm{P}=0.21 ; \mathrm{n}=86$, 1976-2003).

Mean annual mortality rate for 1976-2003 was $1.43 \pm$ SD $1.49 \%$ (Table 1). Annual percentage mortality rate was not dependent on density $\left(R^{2}=0.01 ; \mathrm{df}=26 ; \mathrm{P}=\right.$ $0.84)$. Male and female mortality rates differed at each

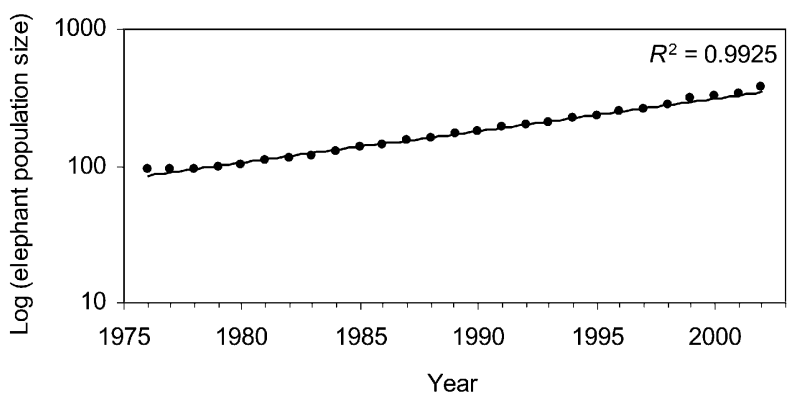

Fig. 2 Logged growth curve of the elephant population of Addo Elephant National Park for 1976-2002. age class (Table 2) with males tending to have higher rates (Mann-Whitney $\mathrm{U}$ test $T=246.0 ; \mathrm{n}=14 ; \mathrm{P}=$ $0.051)$. The juvenile mortality rate ( $0-9$ years) was $1.02 \pm$ SD $1.94 \%$ with no statistical difference between male and female rates $(z=0.52 ; \mathrm{P}=0.61)$. The adult $(\geqslant 10$ years) mortality rate was $1.6 \% \pm$ SD 1.68 and the male rate $(2.81 \%)$ was significantly higher $(z=3.93 ; \mathrm{P}<0.001)$ than the female rate $(0.80 \%)$.

\section{Discussion}

The elephant mean population growth of $5.8 \%$ per annum in Addo Elephant National Park approaches the estimated maximum rate of increase of stable age elephant populations (7\%; Calef, 1988). Furthermore, density did not affect the growth rate or any of the other demographic rates examined. The mean age of first calving was younger (12.5 vs 13.7 years) and the mean inter-calf interval ( 3.3 vs $3.5-4.5$ years) was slightly shorter in the Park compared to other populations (Hanks, 1972; Moss, 2001).

The elephant birth rate in the Park correlated positively with rainfall in the year of conception, as found in Amboseli (Moss, 2001). High rainfall may 


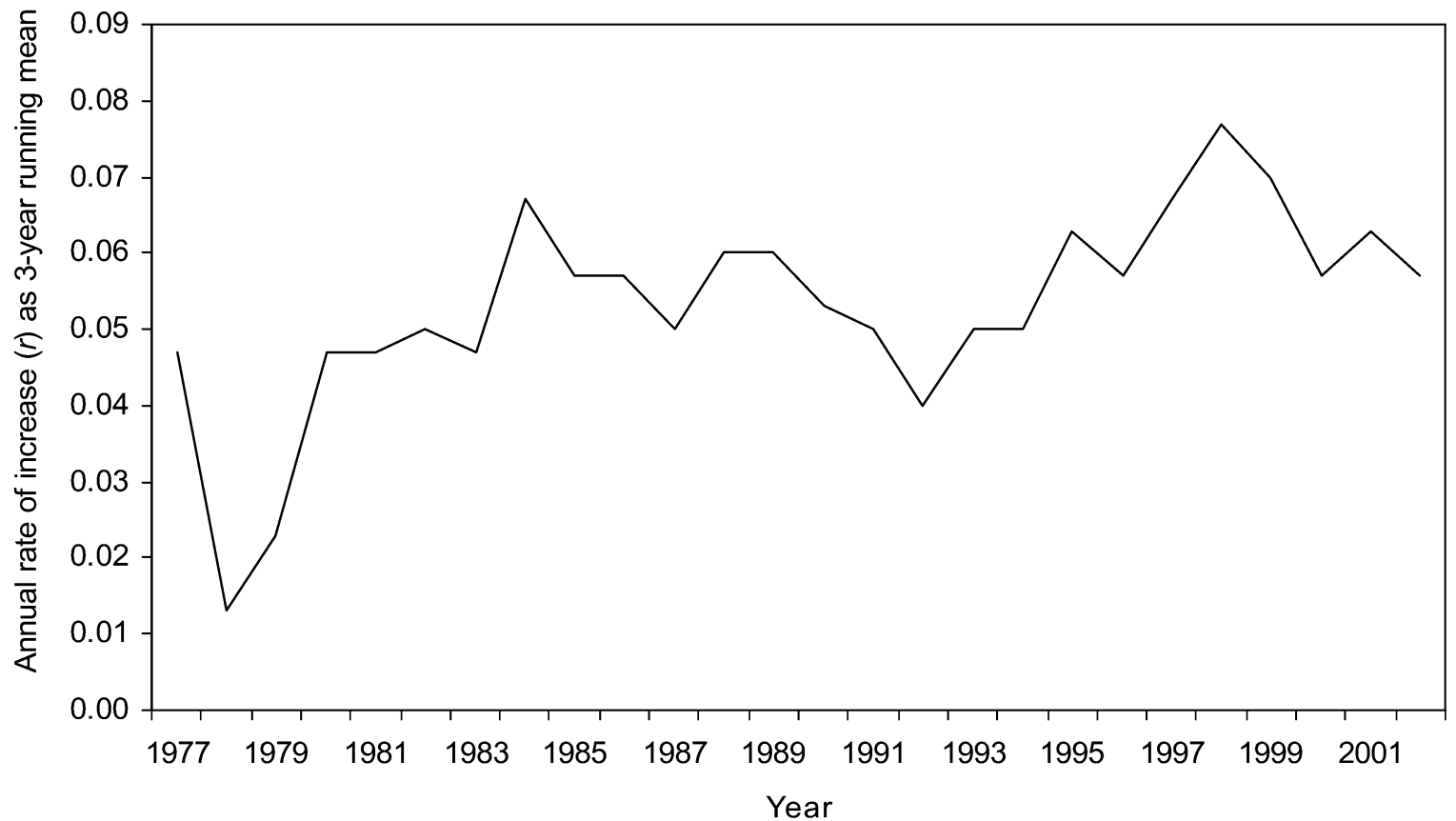

Fig. 3 Exponential rate of increase, $r$, using a 3-year running mean, for the Addo Elephant National Park elephant population during 19762002. The park was enlarged in 1977, 1982, 1984, 1990 and 1997 (Lombard et al., 2001).

Table 2 Age and sex specific mortality rates for the Addo Elephant National Park elephant population for 1976-2003. Z-tests were used to determine if there were significant differences between male and female rates.

\begin{tabular}{|c|c|c|c|c|c|}
\hline \multirow[b]{2}{*}{ Age class } & \multicolumn{2}{|c|}{ Mortality rate (\%) } & \multirow[b]{2}{*}{ Total } & \multirow[b]{2}{*}{$z$} & \multirow[b]{2}{*}{$\mathrm{P}$} \\
\hline & Male & Female & & & \\
\hline 0 & 3.5 & 4.6 & 4.0 & 0.23 & 0.82 \\
\hline 1 & 0.0 & 0.6 & 0.3 & 0.05 & 0.96 \\
\hline 2 & 1.8 & 0.0 & 1.0 & 1.05 & 0.29 \\
\hline 3 & 2.0 & 0.4 & 1.7 & 4.98 & $0.001^{*}$ \\
\hline 4 & 0.7 & 0.0 & 0.4 & 2.89 & $0.004^{*}$ \\
\hline $5-9$ & 0.4 & 0.2 & 0.3 & 0.04 & 0.97 \\
\hline 10-14 & 0.8 & 0.0 & 0.4 & 6.05 & $0.001^{*}$ \\
\hline 15-19 & 1.9 & 0.6 & 1.1 & 1.11 & 0.27 \\
\hline $20-24$ & 3.4 & 0.0 & 1.4 & 2.51 & $0.01^{*}$ \\
\hline $25-29$ & 4.7 & 0.5 & 2.1 & 2.18 & $0.03^{*}$ \\
\hline 30-34 & 5.4 & 0.0 & 1.9 & 1.64 & $0.03^{*}$ \\
\hline $35-39$ & 10.6 & 2.3 & 5.3 & 1.65 & 0.10 \\
\hline 40-44 & 7.7 & 2.4 & 4.3 & 0.04 & 0.67 \\
\hline $45-49$ & 0.0 & 3.2 & 2.6 & & \\
\hline $50-54$ & $\mathrm{n} / \mathrm{a}$ & 0.0 & 0.0 & & \\
\hline 55-59 & $\mathrm{n} / \mathrm{a}$ & 0.0 & 0.0 & & \\
\hline $60-64$ & $\mathrm{n} / \mathrm{a}$ & 41.7 & 41.7 & & \\
\hline
\end{tabular}

*Male mortality rates significantly higher than those of females. $\mathrm{n} / \mathrm{a}$, not available; i.e. no animals in the population have reached this age class or have died.

increase plant nutrient levels, thereby positively influencing birth rates, as shown for a number of rodent species (Reichman \& Van De Graff, 1975; Taylor \&
Green, 1976). McCullagh (1969) observed a period of growth and higher cellular metabolism during the wet season in elephants of Murchison Falls National Park, Uganda, which he linked to the availability of new, nutritious vegetation.

The sex ratio of calves did not deviate from parity and no relationship between the sex ratio and density or rainfall was found. Lee \& Moss (1986) found that during dry years male calves had elevated mortality levels in the first year of life, possibly because mothers could not provide enough milk. Unlike the Amboseli population the elephants of Addo Elephant National Park have year round access to drinking water and drought resistant vegetation (Stuart-Hill \& Aucamp, 1993) in an environment that receives year-round rainfall. This probably explains the extremely low calf and juvenile mortality rates found in the Park compared to other populations, e.g. $4 \%$ for $0-1$ years compared to $10 \%$ (Moss, 2001) and $1.0 \%$ for $0-9$ years compared to $10 \%$ (Laws \& Parker, 1968; Douglas-Hamilton, 1972). The male mortality rate tended to be significantly higher than that of females, which supports findings by Moss (2001), although adult mortality rates in the Park are also lower than those described elsewhere (1.6\% compared to 3-5\%, Laws \& Parker, 1968; Douglas-Hamilton, 1972).

The findings indicate that the vital rates of the elephants of the Park are not following the expected sequence (Gaillard et al., 2000; Eberhardt, 2002) of a population operating under density dependent 
mechanisms: the juvenile mortality rate is low, the age of first breeding is young, birth rate is high and not influenced by density, and adult female mortality rate is low. Furthermore, all these parameters are independent of density.

The demographic data indicates that the elephant population of Addo Elephant National Park is healthy and will continue to increase exponentially. This suggests two things: either that the population has not reached a sustainable carrying capacity, assuming that regulatory mechanisms will be evident once it does, or that elephants will not respond to density dependent processes until the ecosystem is highly altered and damaged. Given that elephant density within the Park is much higher (2.4 elephant $\mathrm{km}^{-2}$ ) than recommended to maintain the vegetation (Penzhorn et al., 1974; Boshoff et al., 2002) and that the population is still growing rapidly, we conclude that resource requirements are currently being met. It is also apparent that the demographic data do not provide any insights into the appropriate densities for these landscapes.

Addo Elephant National Park is situated in a succulent thicket vegetation type (Hall-Martin, 1980, 1992; Cowling, 1984) that is evergreen and nutritious (Koen et al., 1988; Seydack \& Bigalke, 1992; Stuart-Hill \& Aucamp, 1993). It has a high standing biomass (mean wet plant biomass of $18 \mathrm{~kg} \mathrm{~m}^{-2}$, Penzhorn et al., 1974) that accumulates over a number of years, despite a relatively low productivity (Stuart-Hill \& Aucamp, 1993; Henley, 2001). The high nutritional value of thicket can influence herbivore life history; Seydack \& Bigalke (1992) found that bush pig Potamochoerus porcus living in the succulent thicket of the Eastern Cape had higher reproductive rates than those living in the Southern Cape forest. Undisturbed thicket maintains its forage production in drought and has a relatively consistent forage flow between seasons. However, once it has become overgrazed it loses secondary productivity (Stuart-Hill \& Aucamp, 1993), an apparently irreversible, positive feedback process that once initiated, continues (Lechmere-Oertel et al., 2005). Numerous studies within Addo Elephant National Park describe a loss of plant biodiversity (with up to 70 plant species at risk) and biomass, and attribute this to high elephant density (Penzhorn et al., 1974; Midgley \& Joubert, 1991; Lombard et al., 2001; Kerley \& Landman, 2006; M. Landman, unpub. data). The amount of forage available has been substantially reduced yet the elephant population of the Park continues to increase. Because of their large body size, hind-gut digestion, and rapid throughput, elephants are able to utilize a wide range of forage quality (Owen-Smith, 1988). The ability of elephants to utilize a diverse range of plants in the diet (146 species in Addo Elephant National Park, M. Landman, unpub. data) further enhances their ability to extract nutrients from resources with declining availability and variation in quality.

The observed decline in plant biomass and the lack of response in elephant demography allows us to predict that at some point elephants will severely deplete the accumulated forage resources (the basis for further productivity). Until the resource base in the Park is irreversibly damaged, the elephant population will probably continue to reproduce and grow at a high rate, at the expense of biodiversity. A key finding of this study is that elephant demographic data cannot be used to predict when this resource base will collapse; other elements of biodiversity are already providing warnings that densities in the Park are too high. Although there was evidence for density dependence in Kruger National Park (van Aarde et al., 1999), Whyte et al. (2003) surmised that it may be too late for some plant and animal species by the time the elephant population stabilizes. This will be the case in the Addo Elephant National Park and management strategies here or in other aseasonal environments should not therefore rely on the elephant population stabilizing through density dependence before serious damage to the habitat has occurred.

\section{Acknowledgements}

We thank the South African National Parks Board for permission to work in Addo Elephant National Park and the International Fund for Animal Welfare for funding this research. We are grateful to M. Hayward, S. Pimm, A. Shrader and an anonymous reviewer for valuable suggestions that improved this manuscript.

\section{References}

Barnes, R.F.W. (1983) Effects of elephant browsing on woodlands in a Tanzanian national park: measurements, models and management. Journal of Applied Ecology, 20, 521-540.

Ben-Shahar, R. (1993) Patterns of elephant damage to vegetation in Northern Botswana. Biological Conservation, 65, 249-256.

Boshoff, A.F., Kerley, G.I.H., Cowling, R.M. \& Wilson, S.L. (2002) The potential distributions, and estimated spatial requirements and population sizes, of the medium to largesized mammals in the planning domain of the Greater Addo Elephant National Park project. Koedoe, 45, 85-116.

Buss, I.O. \& Savidge, J.M. (1966) Changes in population numbers and reproductive rate of elephants in Uganda. Journal of Wildlife Management, 30, 791-809.

Calef, G.W. (1988) Maximum rate of increase in the African elephant. African Journal of Ecology, 26, 323-327.

Caughley, G. \& Sinclair, A.R.E. (1994) Wildlife Ecology and Management. Blackwell Science, Oxford, UK.

Clark, M.M., Bone, S. \& Galef Jr, B.G. (1990) Evidence of sexbiased postnatal maternal investment by Mongolian gerbils. Animal Behaviour, 39, 735-744. 
Clutton-Brock, T.H., Albon, S.D. \& Guinness, F.E. (1981) Parental investment in male and female offspring in polygynous mammals. Nature, 289, 487-489.

Clutton-Brock, T.H., Major, M., Albon, S.D. \& Guinness, F.E. (1987) Early development and population dynamics in red deer. I. Density-dependent effects on juvenile survival. Journal of Animal Ecology, 56, 53-67.

Clutton-Brock, T.H., Stevenson, I.R., Marrow, P., MacColl, A.D., Houston, A.I. \& McNamara, J.M. (1996) Population fluctuations, reproductive costs and life-history tactics in female Soay sheep. Journal of Animal Ecology, 65, 675-689.

Cowling, R.M. (1984) A syntaxonomic and synecological study in the Humansdorp region of the fynbos biome. Bothalia, 15, 175-227.

Cumming, D.H.M., Brock Fenton, M., Rautenbauch, I.L., Taylor, R.D., Cumming, G.S., Cumming, M.S., Dunlop, J.M., Ford, A.G., Hovorka, M.D., Johnston, D.S., Kalcounis, M., Mahlangu, Z. \& Portfors, C.V.R. (1997) Elephants, woodlands and biodiversity in southern Africa. South African Journal of Science, 93, 231-236.

Douglas-Hamilton, I. (1972) On the ecology and behaviour of the African elephant. PhD thesis, University of Oxford, UK.

Dunham, K.M. (1988) Demographic changes in the Zambezi Valley elephants. Journal of Zoology, 215, 382-388.

Eberhardt, L.L. (2002) A paradigm for population analysis of long-lived vertebrates. Ecology, 83, 2841-2854.

Fowler, C.W. (1987) A review of density dependence. In Populations of Large Mammals (ed. H.H. Genoways), pp. 401-441. Plenum Press, New York, USA and London, UK.

Gaillard, J.-M., Festa-Bianchet, M. \& Yoccoz, N.G. (1998) Population dynamics of large herbivores: variable recruitment with constant adult survival. Trends in Ecology and Evolution, 13, 58-63.

Gaillard, J.-M., Festa-Bianchet, M., Yoccoz, N.G., Loison, A. \& Toigo, C. (2000) Temporal variation in fitness components and population dynamics of large herbivores. Annual Review of Ecology and Systematics, 31, 367-393.

Hall-Martin, A.J. (1980) Elephant survivors. Oryx, 15, 355-362.

Hall-Martin, A.J. (1992) Distribution and status of the African elephant Loxodonta africana in South Africa, 1652-1992. Koedoe, 35, 65-88.

Hanks, J. (1972) Reproduction of elephant, Loxodonta africana, in the Luangwa Valley, Zambia. Journal of Reproduction and Fertility, 30, 13-26.

Hanks, J. \& McIntosh, J.E.A. (1973) Population dynamics of the African elephant (Loxodonta africana). Journal of Zoology, 169, 29-38.

Henley, S.R. (2001) Habitat suitability and modelling for ungulates in a thicket biome, Eastern Cape, South Africa. PhD thesis, University of Port Elizabeth, South Africa.

Hoffman, M.T. (1993) Major P.J. Pretorius and the decimation of the Addo elephant herd in 1919-1920: important reassessments. Koedoe, 36, 23-44.

Kerley, G.I.H. \& Landman, M. (2006) The impacts of elephants on biodiversity in the Eastern Cape Subtropical Thickets. South African Journal of Science, in press.

Koen, J.H., Hall-Martin, A.J. \& Erasmus, T. (1998) Macro nutrients in plants available to the Knysna, Addo, and Kruger National Park elephants. South African Journal of Wildlife Research, 18, 69-71.

Kruuk, L.E.B., Clutton-Brock, T.H., Albon, S.D., Pemberton, J.M. \& Guinness, F.E. (1999) Population density affects sex ratio variation in red deer. Nature, 399, 459-461.
Laws, R.M. (1969) Two Tsavo research projects. Journal of Reproduction and Fertility, 6, 495-531.

Laws, R.M. (1970) Elephants as agents of habitat and landscape change in East Africa. Oikos, 21, 1-15.

Laws, R.M. \& Parker, I.S.C. (1968) Recent studies on elephant populations in East Africa. Symposium of the Zoological Society of London, 21, 319-359.

Lechmere-Oertel, R.G., Cowling, R.M. \& Kerley, G.I.H. (2005) Landscape dysfunction and reduced spatial heterogeneity in soil resources and fertility in semi-arid succulent thicket, South Africa. Austral Ecology, 30, 615-624.

Lee, P.C. \& Moss, C.J. (1986) Early maternal investment in male and female African elephant calves. Behavioral Ecology and Sociobiology, 18, 353-361.

Lewis, D.M. (1991) Observations of tree growth, woodland structure and elephant damage on Colophospermum mopane in Luangwa Valley, Zambia. African Journal of Ecology, 29, 207-221.

Lombard, A.T., Johnson, C.F., Cowling, R.M. \& Pressey, R.I. (2001) Protecting plants from elephants: botanical reserve scenarios within the Addo Elephant National Park, South Africa. Biological Conservation, 102, 191-203.

McCullagh, K. (1969) The growth and nutrition of the African elephant. I. Seasonal variations in the rate of growth and the urinary excretion of hydroxyproline. East African Wildlife Journal, 7, 85-90.

Midgley, J.J. \& Joubert, D. (1991) Mistletoes, their host plants and the effects of browsing by large mammals in Addo Elephant National Park. Koedoe, 34, 149-152.

Moolman, H.J. \& Cowling, R.M. (1994) The impact of elephant and goat grazing on the endemic flora of South African succulent thicket. Biological Conservation, 68, 53-61.

Moss, C.J. (2001) The demography of an African elephant (Loxodonta africana) population in Amboseli, Kenya. Journal of Zoology, 255, 145-156.

Mysterud, A., Yoccoz, N.G., Stenseth, N.C. \& Langvatn, R. (2000) Relationships between sex ratio, climate and density in red deer: the importance of spatial scale. Journal of Animal Ecology, 69, 959-974.

Owen-Smith, R.N. (1988) Megaherbivores: The Influence of Very Large Body Size on Ecology. Cambridge University Press, Cambridge, UK.

Penzhorn, B.L., Robbertse, P.J. \& Olivier, M.C. (1974) The influence of the African elephant on the vegetation of the Addo Elephant National Park. Koedoe, 17, 137-158.

Reichman, O.J. \& Van De Graaff, K. (1975) Association between ingestion of green vegetation and desert rodent reproduction. Journal of Mammalogy, 56, 503-507.

Seydack, A.H.W. \& Bigalke, R.C. (1992) Nutritional ecology and life history tactics in the bushpig (Potamochoerus porcus): development of an interactive model. Oecologia, 90, 102-112.

Stuart-Hill, G.C. \& Aucamp, A.J. (1993) Carrying capacity of the succulent valley bushveld of the Eastern Cape. African Journal of Range and Forage Science, 10, 1-10.

Taylor, K.D. \& Green, M.G. (1976) The influence of rainfall on diet and reproduction in four African rodent species. Journal of Zoology, 180, 367-389.

Trivers, R.L. \& Willard, D.E. (1973) Natural selection of parental ability to vary the sex ratio of offspring. Science, 179, 90-92.

van Aarde, R., Whyte, I. \& Pimm, S. (1999) Culling and the dynamics of the Kruger National Park African elephant population. Animal Conservation, 2, 287-294.

van Jaarsveld, A.S., Nicholls, A.O. \& Knight, M.H. (1999) Modelling and assessment of South African elephant 
Loxodonta africana population persistence. Environmental Modeling and Assessment, 4, 155-163.

Van Wyk, P. \& Fairall, N. (1969) The influence of the African elephant on the vegetation of the Kruger National Park. Koedoe, 9, 57-95.

Western, D. \& Gichohi, H. (1989) Segregation effects and the impoverishment of savanna parks: the case for ecosystem viability analysis. African Journal of Ecology, 31, 269-281.

Whitehouse, A.M. (2001) The Addo elephants: conservation biology of a small closed population. PhD thesis, University of Port Elizabeth, South Africa.

Whitehouse, A.M. \& Hall-Martin, A.J. (2000) Elephants in Addo Elephant National Park, South Africa: reconstruction of the population's history. Oryx, 34, 46-55.

Whyte, I.J., van Aarde, R. \& Pimm, S.L. (2003) Kruger's elephant problem: its size and consequences for ecosystem heterogeneity. In The Kruger Experience: Ecology and Management of Savannah Heterogeneity (eds J.T. du Toit, K.H. Rogers \& H.C. Biggs), pp. 332-348. Island Press, London, UK.

Wilson, K. \& Hardy, I.C.W. (2002) Statistical analysis of sex ratios: an introduction. In Sex Ratios: Concepts and Research
Methods (ed. I.C.W. Hardy), pp. 48-92. Cambridge University Press, Cambridge, UK.

Wolff, J.O. (1988) Maternal investment and sex ratio adjustment in American bison calves. Behavioral Ecology and Sociobiology, 23, 127-133

Zacharias, P.J.K. (2004) Rangeland assessment and monitoring: the elusive elixir. African Journal of Range $\mathcal{E}$ Forage Science, 21, 101-108.

\section{Biographical sketches}

Katie Gough's research focuses on the elephants of the Addo Elephant National Park, primarily their demography, behaviour and conservation management.

Graham Kerley is Director of the Centre for African Conservation Ecology. He also serves as a member of the Eastern Cape Parks Board. His research interests lie in the fields of animal plant interactions and conservation biology and he has been involved in research on species ranging from rodents to megaherbivores. 